\title{
Bleach Boosting and Direct Brightening by Multiple Xylanase Treatments During Peroxide Bleaching of Kraft Pulps
}

\author{
Ken K. Y. Wong, ${ }^{*}$ Lori A. Martin, F. Miguel Gama, ${ }^{*}$ John N. Saddler, \\ Ed de Jong
}

Department of Wood Science, University of British Columbia, \#270-2357 Main Mall, Vancouver, British Columbia V1T 1Z4, Canada

Received 8 January, 1996; accepted 27 September, 1996

\begin{abstract}
The effects of multiple xylanase treatments were assessed during the peroxide bleaching of three pulps: Douglas-fir (kraft); Western hemlock (oxygen delignified kraft); and trembling Aspen (kraft). The addition of a xylanase treatment stage, either before or after the peroxide bleaching stage(s), resulted in the enhanced brightening of all pulps. A higher brightness was achieved using two enzyme treatments, one before and one after the peroxide stage(s). Both bleach boosting and direct brightening seemed to contribute to the enhancement of peroxide bleaching. Compared to xylanase prebleaching, xylanase posttreatment of the peroxide bleached pulps solubilized less lignin and chromophores and made smaller amounts of these materials alkaline soluble. Nevertheless, the final brightness achieved by xylanase posttreatment was similar or superior to that achieved with xylanase prebleaching of the corresponding unbleached pulps. (C) 1997 John Wiley \& Sons, Inc. Biotechnol Bioeng 54: 312-318, 1997.
\end{abstract}

Keywords: xylanase; kraft pulp; peroxide bleaching

\section{INTRODUCTION}

It has been a decade since the first report that xylanase enhances the chemical bleaching of kraft pulp (Viikari et al., 1994). This hydrolytic enzyme depolymerizes xylan, a polysaccharide found in plant cell walls and wood pulps. Xylanase is not expected to directly modify residual lignin, the polyphenolic component of wood pulp commonly thought to be responsible for its color (Hartler and Norrström, 1969; Schwartz et al., 1940). Therefore, it is not clear how xylanase can reduce the amounts of chemicals required to bleach kraft pulp to desired brightness levels. A number of hypotheses have been forwarded concerning the nature of the target substrates for xylanase (Wong and Saddler, 1992), and they include xylan-derived chromophores, xylan in lignin-carbohydrate complexes, xylan that physically entraps lignin, and xylan that influences fiber swelling.

An apparent consensus has been that xylanase makes

* Present address: Pulp \& Paper Research Organisation of New Zealand, NZ FRI Ltd., Private Bag RO 3020, Rotorua, New Zealand

** Present address: Department of Biological Engineering, University of Minho, Braga, Portugal

Correspondence to: K. K. Y. Wong kraft pulp more amenable to chemical bleaching, without brightening or delignifying the pulp during the xylanase prebleaching stage (Viikari et al., 1994). This phenomenon, where the brightness gain achieved after subsequent chemical bleaching is substantial while that before chemical bleaching is negligible, has been coined "bleach boosting." It differs from direct brightening in which an increase in pulp brightness occurs immediately following the enzyme stage.

Bleach boosting has been advocated as the main mechanism of xylanase action on kraft pulp, primarily because any report of direct brightening (Pham et al., 1995; Ragauskas et al., 1994; Senior et al., 1992; Yang and Eriksson, 1992) or direct decrease in the kappa number of the pulp (Hortling et al., 1994; Paice et al., 1988) has been considered insignificant. However, past work in our laboratories has consistently shown that direct brightening occurs in oxygen delignified kraft pulps (henceforth referred to as kraft-oxygen pulps) derived from softwoods, and peroxide bleached kraft pulps (Nelson et al., 1995; Wong et al., 1996). Furthermore, very recent work in another laboratory has led to the hypothesis that xylan contributes to the kappa number of pulp because its methylglucuronic acid substituents are converted to hexenuronic acid substituents under alkaline pulping and bleaching conditions (Buchert et al., 1995). It is therefore important to compare systematically the contribution that bleach boosting and direct brightening have on pulp brightness because one process might be more dependent on subsequent lignin removal and the other on direct xylan removal. Not only would this evaluation provide new insights on the mechanisms by which xylanase enhances pulp bleaching, it may also have important implications for the application of xylanase in kraft mills.

\section{MATERIALS AND METHODS}

\section{Enzyme}

The commercial xylanase used was Irgazyme 40S-4X (Genencor, USA), an enzyme preparation from Trichoderma longibrachiatum. The DNS-xylanase assay of Bailey et al. 
(1992) indicated that the enzyme had an activity of 360 nkat $/ \mu \mathrm{L}$ in $50 \mathrm{~m} M \mathrm{Na} \cdot$ phosphate buffer at $\mathrm{pH} 7$.

\section{Kraft Pulps}

Brownstock pulps, or unbleached kraft pulps, derived from Douglas-fir (Pseudotsuga menziesii) and trembling aspen (Populus tremuloides) were prepared by Mr. Wai Gee in the pilot plant at the Pulp and Paper Research Institute of Canada (Vancouver, BC). Kraft-oxygen pulp derived from the Western hemlock (Tsuga heterophylla) was produced at Howe Sound Pulp \& Paper (Port Mellon, BC) using a modified continuous cooked pulp from a Kamyr digester. All pulp samples were washed extensively by screening with a 200-mesh screen. The composition of the pulp (Table I) was determined as described previously (Yokota et al., 1995).

\section{Bleaching Conditions}

The standard bleaching sequence used was XQPP, where $\mathrm{X}$ $=$ xylanase treatment, $\mathrm{Q}=$ chelation, $\mathrm{P}=$ peroxide, and $\mathrm{C}$ $=$ control treatment replacing $\mathrm{X}$. The additional stages performed include an X stage after each P stage, and an alkaline extraction (E) after all X stages (Fig. 1). All bleaching and extraction stages were done in polyester bags, whereas enzyme treatments of partially bleached pulp (QPX and QPPX) were performed in common polyethylene bags. The $\mathrm{pH}$ adjustments before the $\mathrm{X}$ and $\mathrm{Q}$ stages were done using $\mathrm{H}_{2} \mathrm{SO}_{4}$ and $\mathrm{NaOH}$ while stirring the pulp at $1 \%$ consistency in deionized water for $1 \mathrm{~h}$. The pulp samples were thoroughly mixed with the bleaching reagents, once at the beginning of each stage, and once before filtrate samples were taken after all $\mathrm{X}$ and $\mathrm{E}$ stages. After each stage, the pulp was washed at $1 \%$ consistency in deionized water. Each time the pulp was drained, the filtrate was passed through the pulp cake three times to collect the fines. The conditions for the $\mathrm{X}$ stage were start $\mathrm{pH}$ of 7 , no buffer added, $10 \%$ pulp

Table I. The percent composition of pulp samples and their microkappa number after enzyme and control treatments.

\begin{tabular}{lccr}
\hline \multicolumn{1}{c}{ Component } & $\begin{array}{c}\text { Douglas-fir } \\
\text { kraft }\end{array}$ & $\begin{array}{c}\text { Hemlock } \\
\text { kraft-oxygen }\end{array}$ & $\begin{array}{r}\text { Aspen } \\
\text { kraft }\end{array}$ \\
\hline $\begin{array}{l}\text { Carbohydrate }^{\mathrm{a}} \\
\text { Arabinose }\end{array}$ & 0.36 & 0.36 & 0.04 \\
Galactose & 0.48 & 0.45 & 0.09 \\
Glucose & 83.09 & 76.02 & 76.17 \\
Mannose & 3.99 & 7.30 & $\mathrm{ND}^{\mathrm{b}}$ \\
Xylose & 4.75 & 5.87 & 18.09 \\
Lignin & & & \\
Acid insoluble & 4.00 & 3.29 & 2.25 \\
Acid soluble & 0.42 & 0.38 & 0.91 \\
Microkappa number & & & \\
$\quad$ Control & 25.4 & 16.6 & 13.1 \\
Enzyme-treated & 24.1 & 15.9 & 12.0 \\
\hline
\end{tabular}

${ }^{\mathrm{a}}$ Composition is reported for the anhydro-form of the monosaccharide. ${ }^{b}$ Not detectable.

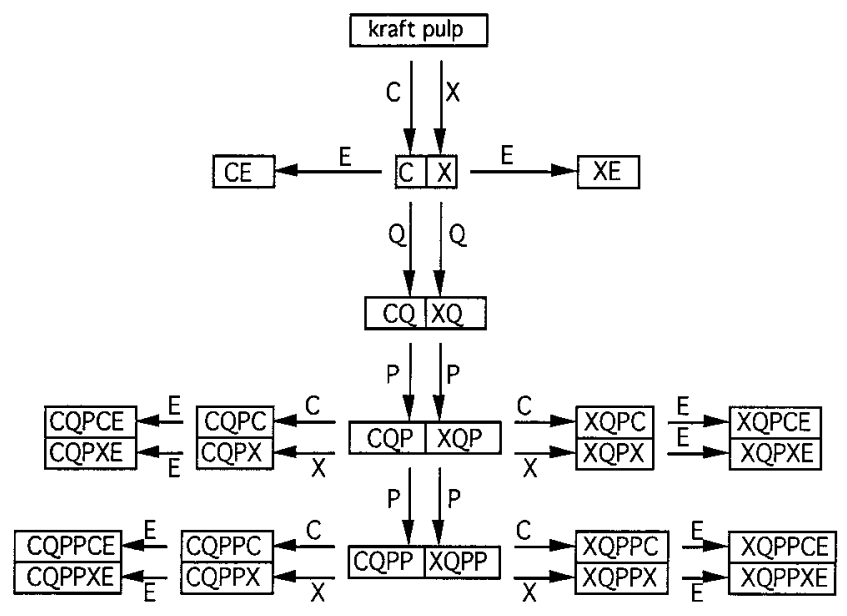

Figure 1. Experimental scheme showing the labeling of each pulp sample in a box. The bleaching stages performed are shown by labeled arrows, where $\mathrm{C}=$ control treatment with boiled enzyme, $\mathrm{X}=$ xylanase treatment, $\mathrm{E}=$ alkaline extraction, $\mathrm{Q}=$ chelation, and $\mathrm{P}=$ peroxide.

consistency, 400 nkat enzyme/g pulp, at $50^{\circ} \mathrm{C}$ for $1 \mathrm{~h}$. The $\mathrm{Q}$ stage required a start $\mathrm{pH}$ of $5.5,3 \%$ consistency, $1 \%$ EDTA, at $50^{\circ} \mathrm{C}$ for $30 \mathrm{~min}$. The conditions for the $\mathrm{P}$ stages were $10 \%$ consistency, $0.05 \% \mathrm{MgSO}_{4} \cdot 7 \mathrm{H}_{2} \mathrm{O}, 2 \% \mathrm{NaOH}$, $4 \% \mathrm{H}_{2} \mathrm{O}_{2}$, at $80^{\circ} \mathrm{C}$ for $3 \mathrm{~h}$. The $\mathrm{E}$ stage conditions were $10 \%$ pulp consistency, $2 \% \mathrm{NaOH}$, at $80^{\circ} \mathrm{C}$ for $1 \mathrm{~h}$. Chemical loadings were based on the dry weight equivalent of pulp. The controls were treated with enzyme that had been heat inactivated.

\section{Pulp Characterization}

Pulp samples were collected after every stage except the chelation stage. They were adjusted to $\mathrm{pH} 5.5$ at $1 \%$ consistency, drained, and then stored in darkness at $4^{\circ} \mathrm{C}$ before testing. Handsheets were made according to CPPA standard C.5 using $4 \mathrm{~g}$ of pulp, and their brightness $(\lambda=457 \mathrm{~nm})$ measured using a Technibrite Micro TB-1C instrument (Technidyne Corp., New Albany, IN). The amount of residual lignin in pulp was measured using the microkappa procedure (Tappi Useful Method UM 246, 1991).

\section{Filtrate Analyses}

The $\mathrm{X}$ filtrates were boiled for $10 \mathrm{~min}$, and all filtrates were passed through glass microfiber filters (Whatman 943-AH) to remove any particulates. The amount of sugar present was measured using the phenol-sulfuric acid assay (Dubois et al., 1956), with xylose used as the standard and with a second determination done by spiking the samples with known amounts of the standard. Lignin and chromophore content was determined by measuring absorbance at 280 and $457 \mathrm{~nm}$, respectively. The samples were diluted with 50 $\mathrm{m} M \mathrm{Na} \cdot$ phosphate buffer, $\mathrm{pH} 7.0$, to give readings between 0.2 and $0.7 \mathrm{AU}$. 


\section{RESULTS}

\section{Pulp Brightness}

After the control treatment, the brightness of the Douglas-fir kraft, hemlock kraft-oxygen, and aspen kraft pulps was $28.8 \%, 32.1 \%$, and $41.6 \%$ ISO, respectively. Irgazyme 40 increased the brightness of the Aspen kraft and hemlock kraft-oxygen pulps after the X, XQP, and XQPP bleaching sequences, and that of Douglas-fir kraft pulp only after the latter two sequences (Fig. 2). Therefore, both direct brightening after enzyme treatment and bleach boosting after subsequent chemical bleaching occurred. The former effect occurred in two of the three pulps, where there was a brightness gain of $0.3 \%$ to $0.8 \%$ ISO immediately after the enzyme stage. The latter effect occurred in all unbleached pulp, where the gain in final pulp brightness reached values as high as $1.2 \%$ ISO.

A second enzyme treatment of peroxide bleached pulp also had a direct effect on pulp brightness (Fig. 2), and this was obtained both after one and two peroxide stages (XQPX, XQPPX). Pulps that were treated with the boiled enzyme before bleaching (CQPX, CQPPX) generally showed a larger direct brightening effect. Nevertheless, the final pulp brightness was consistently the highest when the pulp received two enzyme treatments, and this was particularly evident after two peroxide stages. Although the Aspen kraft pulp showed a low $(<0.3 \%$ ISO) brightness gain, with a second enzyme treatment after two peroxide stages, this gain appeared significant even when pulp brightness was near $85 \%$ ISO. The pulp brightness achieved by two enzyme treatments was nearly matched by single enzyme treatments in only two cases, specifically the Aspen and Douglas-fir kraft pulps treated with the CQPX sequence.

When pulp brightness obtained after XQP bleaching was compared with the values obtained after XQPC (Fig. 2), it was apparent that the control treatment at $50^{\circ} \mathrm{C}$ further increased the brightness of the peroxide bleached, Aspen kraft, and hemlock kraft-oxygen pulps by approximately $1 \%$ ISO. This brightness increase obtained after such a pulp wash was also seen after two peroxide stages, although to a lesser extent ( $\sim 0.4 \%$ ISO). When the two softwood pulps were treated with boiled enzyme only, there was no difference between the pulp brightness after $\mathrm{CQP}(\mathrm{P})$ and $\mathrm{CQP}(\mathrm{P}) \mathrm{C}$ treatments. However, washing of Aspen kraft pulps appeared to have a greater role because brightness gains of $0.4 \%$ to $1.2 \%$ ISO were achieved after the second boiled enzyme step.

The extraction of the xylanase-treated pulps with $2 \%$ caustic did not necessarily increase the brightness gain achieved by the enzyme (Fig. 3). After two peroxide bleaching stages, subsequent alkaline extraction in fact decreased the overall brightness of most of the control and enzymetreated pulps. Substantial and consistent increases in pulp brightness (1\% to $3 \%$ ISO), as well as in brightness gains achieved by the enzyme treatment, were only observed for the unbleached pulps (XE). The Douglas-fir kraft pulp showed a brightness gain of $1.2 \%$ ISO after the E stage even though there was no direct brightening during the $\mathrm{X}$ stage. Also, the Aspen kraft and hemlock kraft-oxygen pulps dem-
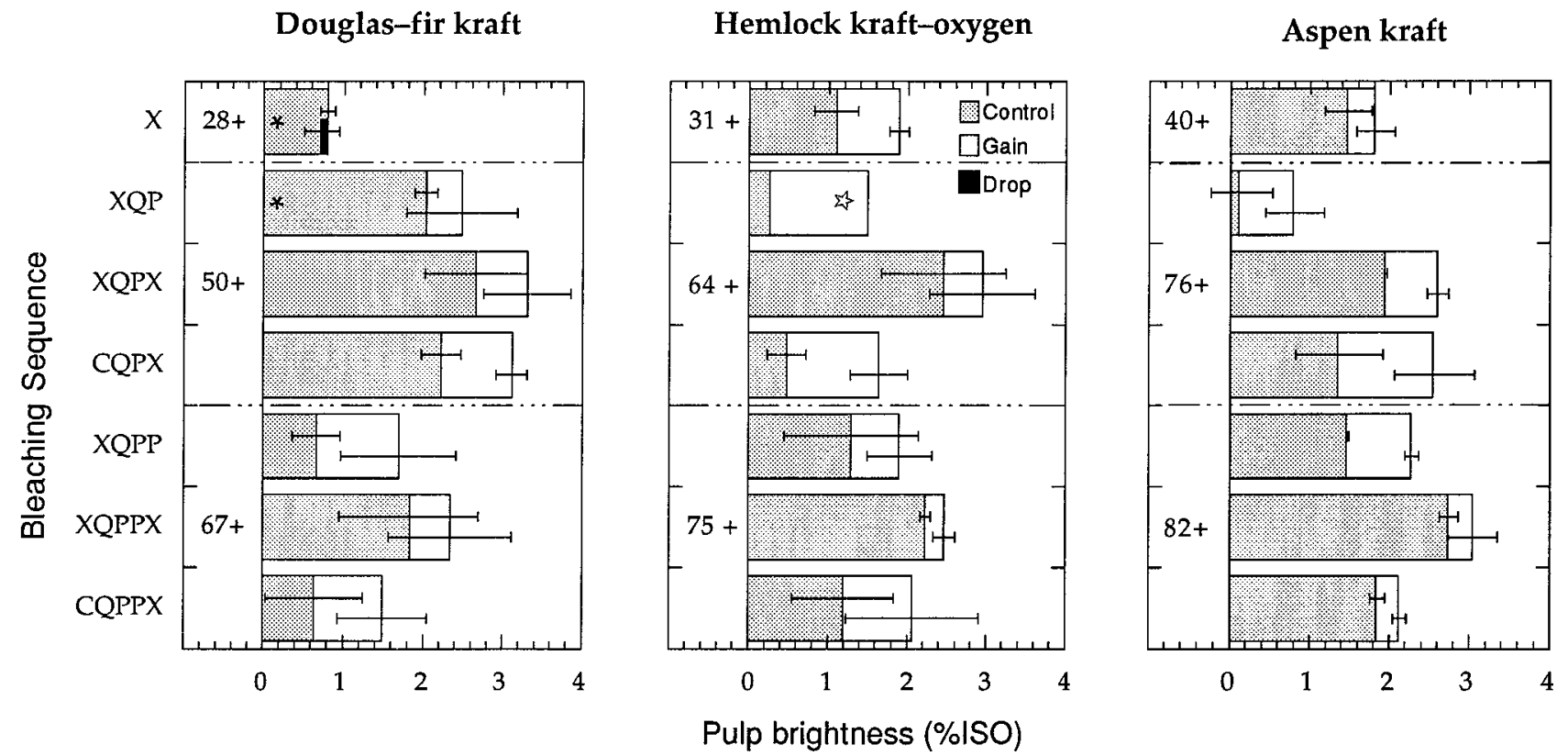

Figure 2. The brightness of the three kraft pulps after enzyme treatment and peroxide bleaching in different sequences. Each histogram shows the pulp brightness achieved by the control sequence, and the gain or drop that was achieved by enzyme treatment. Its value on the $x$-axis should be added to the value shown to the left of the histograms that corresponds to unbleached pulp and the pulps bleached with one and two peroxide stages. The average result from two replicate experiments is shown with its range in all cases except that marked with a star (伩), where only one successful experiment was performed. Brightness gains were observed in both experiments except in the cases marked with an asterisk $(*)$. 
Douglas-fir kraft

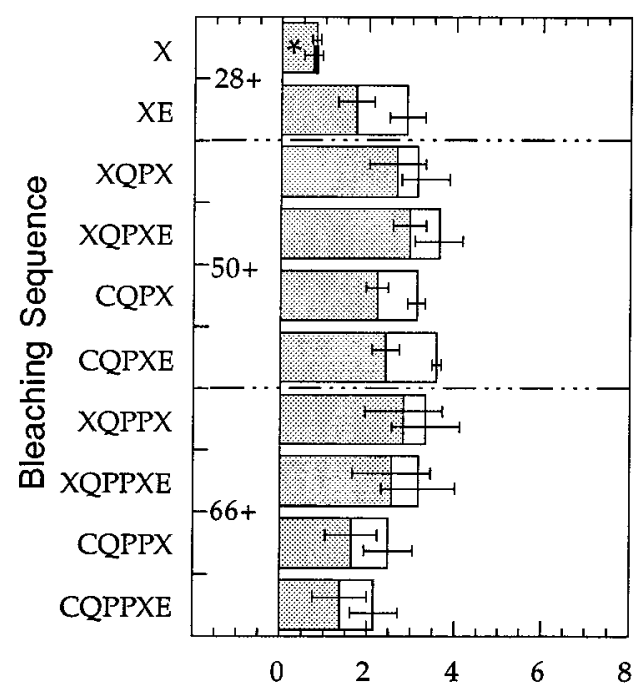

Hemlock kraft-oxygen

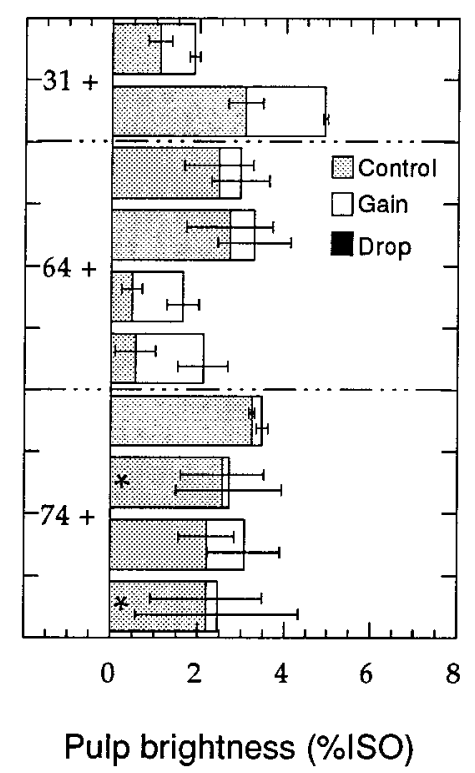

Aspen kraft

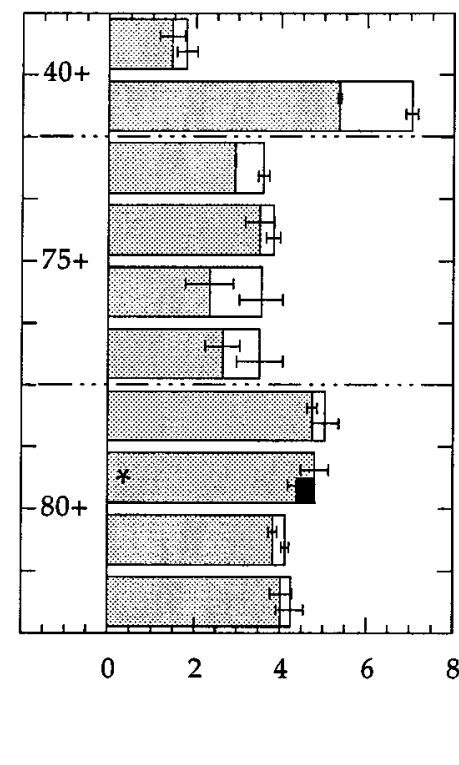

Figure 3. The brightness of the three kraft pulps after the bleaching sequences ending with an enzyme stage and subsequent alkaline extraction. See legend to Figure 2 for further details.

onstrated increased brightness gains after alkaline extraction of the unbleached pulps (Fig. 3).

\section{Kappa Number of Unbleached Pulp}

The kappa numbers of the Douglas-fir kraft, hemlock kraftoxygen, and Aspen kraft pulps were 25.4, 16.6, and 13.1, respectively, and they decreased in all three pulps immediately after the enzyme stage (Table I). The direct kappa drops ranged from 0.7 to 1.3 points, with the largest decrease occurring in the Douglas-fir kraft pulp. The kappa drops were not enhanced by subsequent alkaline extraction (data not shown).

\section{Carbohydrate Solubilization}

The total sugars solubilized from Aspen kraft pulp during the control treatment ( 1 to $2.7 \mathrm{mg} / \mathrm{g}$ pulp) were higher than those from the two softwood pulps $(0.2$ to $1.1 \mathrm{mg} / \mathrm{g})$, and this may be attributed to its higher xylan content (Table I). Also, the increases in sugar solubilization as a result of enzyme treatment were higher for the Aspen pulp (2 to 10.4 $\mathrm{mg} / \mathrm{g}$ ) when compared with the softwood pulps (2 to 4.4 $\mathrm{mg} / \mathrm{g}$ ). The largest increase generally occurred after the CQPX sequence for all three pulps.

\section{Lignin Solubilization}

During control treatments, over four times more lignin (UVabsorbing material) was released into the filtrate from the unbleached Aspen kraft pulp than from either the Douglasfir kraft or hemlock kraft-oxygen pulps (Fig. 4). However, the amount of lignin leached from the peroxide bleached pulps $(\mathrm{XQP}(\mathrm{P}) \mathrm{C}, \mathrm{CQP}(\mathrm{P}) \mathrm{C})$ was often lowest for those derived from Aspen. The enzyme treatment, before or after peroxide bleaching, increased lignin solubilization in all pulps. Among the unbleached pulps, hemlock kraft-oxygen pulp released the most lignin during enzyme treatment. High lignin solubilization also occurred in peroxide bleached pulps, with those derived from Douglas-fir releasing the most lignin and those derived from Aspen generally releasing the least.

An alkaline extraction after the enzyme stage was used to determine whether xylanase increased the extractability of pulp lignin. Much more lignin was extracted from the untreated and unbleached pulp derived from Douglas-fir than from the other two unbleached pulps. A similar trend was also observed among the corresponding peroxide bleached pulps; however, the amounts of lignin extracted were lower. The lignin extractability of both unbleached and bleached pulps was increased after enzyme treatment, with the largest increase occurring for the unbleached pulps. The increase in lignin extraction from peroxide bleached Aspen pulp was consistently higher than the increase in lignin solubilization obtained during the enzyme stage. For bleached pulps derived from Douglas-fir, the opposite trend was observed. The increase in lignin extractability was often higher for the pulp that had received only one enzyme stage.

\section{Chromophore Solubilization}

Absorbance of the filtrate was read in the visible spectrum at $457 \mathrm{~nm}$ to monitor the solubilization of chromophores (Fig. 5). Although no chromophoric material was released 
Douglas-fir kraft

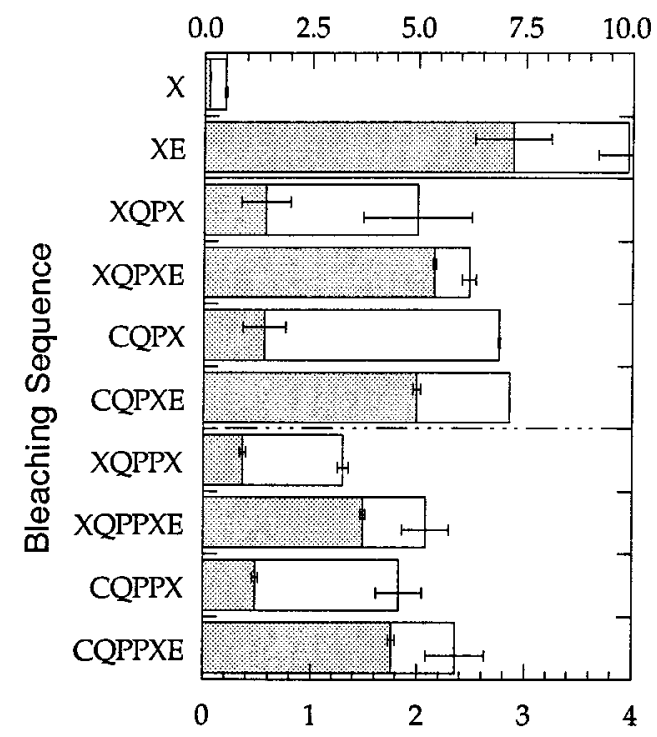

Hemlock kraft-oxygen

Aspen kraft
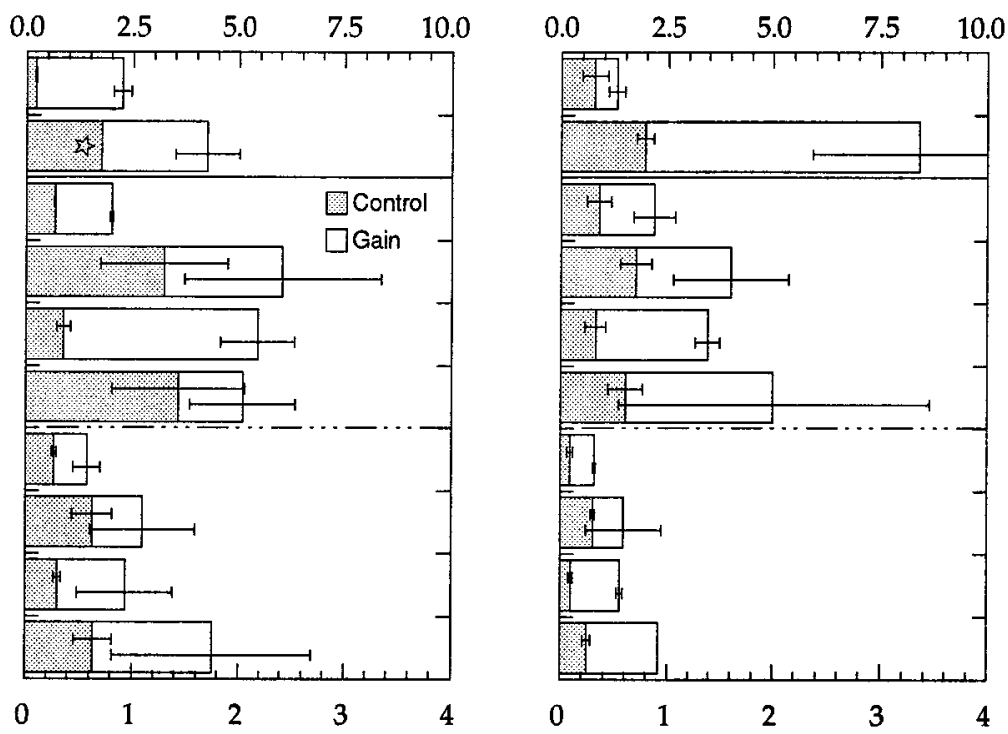

Lignin solubilization $\left(A_{280}\right)$

Figure 4. The increase in lignin solubilization and extractability after enzyme treatment of the three kraft pulps. Lignin in filtrates and extracts was monitored by absorbance at $280 \mathrm{~nm}$. Each histogram shows the result from the control treatment, and the gain achieved by enzyme treatment. The average result from two replicate experiments is shown with its range in all cases except that marked with a star (沦), where only one successful experiment was performed. The scale for the $\mathrm{X}$ and $\mathrm{XE}$ samples is shown at the top and that for the other samples at the bottom.

from the Douglas-fir kraft pulp during the control treatment, increasing amounts were released from the hemlock kraftoxygen pulp and the Aspen kraft pulp. Chromophores were also leached out of the peroxide bleached pulp, usually at lower levels for the more fully bleached pulps. Although Irgazyme solubilized relatively high amounts of chromophores from the unbleached pulps, it released rather low amounts from the corresponding peroxide bleached pulps,
Douglas-fir kraft

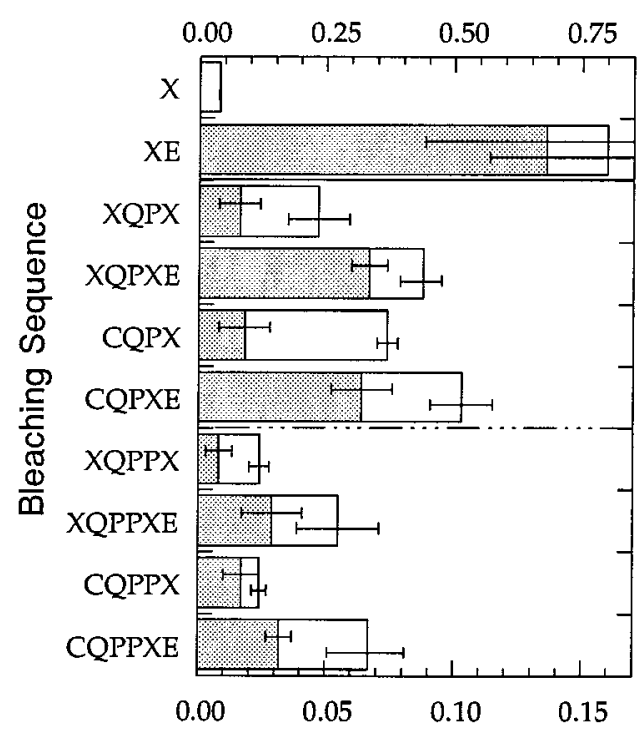

Hemlock kraft-oxygen

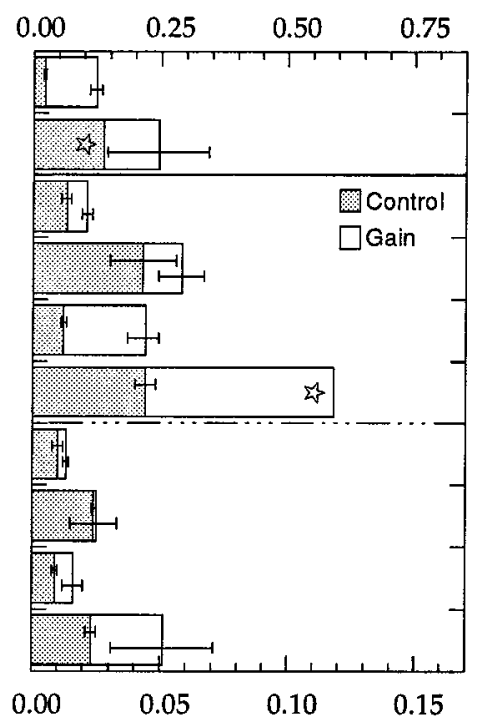

Aspen kraft

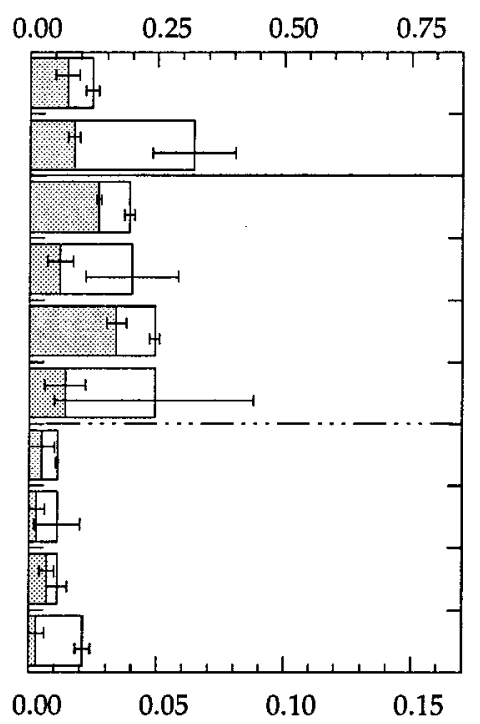

\section{Chromophore solubilization $\left(\mathrm{A}_{457}\right)$}

Figure 5. The increase in chromophore solubilization and extractability after enzyme treatment of the three kraft pulps. Chromophores in filtrates and extracts were monitored by absorbance at $457 \mathrm{~nm}$. See legend to Figure 4 for further details. 
particularly after two peroxide stages. In general, more chromophores were solubilized from the CQPX bleached pulps during the enzyme stage than from the other peroxide bleached pulps.

Alkaline extraction removed additional chromophores from all pulp samples. The largest releases of chromophores were from the unbleached pulps, with that from Douglas-fir kraft pulp being substantially higher. After the bleaching of the Aspen kraft pulp by two peroxide stages, very few chromophores could be extracted by alkali, but Irgazyme nevertheless increased chromophore extractability. Enzyme treatment enhanced chromophore extraction substantially from nearly all pulps, with the highest values obtained with the unbleached pulps.

\section{DISCUSSION}

In the present work, the brightness gains observed as a result of bleach boosting and direct brightening are in the range previously reported during peroxide bleaching of softwood kraft pulps, in laboratory experiments (Nelson et al., 1995; Suurnäkki et al., 1994; van Lierop et al., 1994; Wong et al., 1996) and in a mill trial (Lundgren et al., 1994). Although the reports of direct brightening have been inconsistent in the literature, the present study confirmed our previous results indicating that xylanase can directly brighten partially bleached pulps, such as kraft-oxygen and peroxide bleached pulps, but not unbleached softwood kraft pulp (Nelson et al., 1995; Wong et al., 1996). It also found that a hardwood kraft pulp derived from aspen could be directly brightened to some extent. Because direct brightening has also been observed in model pulps prepared by depositing lignin and xylan on cellulose fibers under alkaline conditions (de Jong et al., 1997b), it remains unclear why direct brightening is only absent in unbleached softwood kraft pulps.

Of the three pulps examined, the Douglas-fir kraft pulp had the lowest xylose content and the highest lignin content and kappa number. The amounts of lignin and chromophore solubilized from this pulp by xylanase were slightly lower than those from Aspen kraft pulp, even though the latter pulp contained much lower amounts of lignin. Because substantially more lignin and chromophores were removed from the Douglas-fir pulp during alkaline extraction, it would appear that its residual lignin is less soluble at neutral $\mathrm{pH}$.

In nearly all cases, xylanase treatment substantially improves the extractability of lignin and chromophores from unbleached kraft pulps. This suggests that a xylanase step is most beneficial if applied before peroxide bleaching, a supposition that seems to be corroborated by the lower amounts of material extracted from peroxide bleached pulps. Recent work also indicated that extensive treatment of pine kraft pulp with xylanase increases lignin coverage of fiber surface area from $17 \%$ to $28 \%$ (Buchert et al., 1996), thus exposing more lignin to extraction and bleaching chemicals. These results and past reports of bleach boosting have helped entrench the view that bleach boosting has a major role in the mechanism of xylanase-aided bleaching of kraft pulp (Hortling et al., 1994; Viikari et al., 1994). However, a thorough examination of our results raises questions as to the importance of bleach boosting. For example, pulp brightness achieved after peroxide bleaching of xylanase prebleached pulp was not higher than that achieved after xylanase posttreatment of peroxide bleached pulp. In another study, Ledoux et al. (Tappi Proceedings of the 1993 Pulp Conference, Atlanta, GA, book 3, pp. 1057-1065) suggested that the final brightness of a hardwood kraft pulp is not greatly dependent on the location of the xylanase stage in an oxygen-peroxide-ozone bleaching sequence.

The target substrates during xylanase prebleaching and xylanase posttreatment may have similar features because there was a release of chromophores and apparent lignin in both cases, corresponding to a drop in the kappa number of the pulp (Nelson et al., 1995; Wong et al., 1996). For peroxide bleached pulps already prebleached with xylanase, there were often smaller amounts of lignin and chromophores solubilized during a second xylanase treatment and subsequent alkaline extraction. Xylanase prebleaching may therefore be removing some of the substrates that would have remained accessible to xylanase posttreatment, after peroxide bleaching. Although the effects of higher xylanase charges during prebleaching have not yet been determined, our observations seem to corroborate a recent report that more lignin and xylan substrates are found underneath the surface layer of xylan and lignin on kraft pulp fibers (Suurnäkki et al., 1996). It is still possible that only portions of these substrates constitute target substrates essential for the enhancement of pulp brightness, and that the target substrates are composed of lignin-carbohydrate complexes, xylan-derived chromophores, or both (de Jong et al., 1997b).

Although xylanase posttreatment might seem to make xylanase prebleaching less important, it remains possible that xylanase can enhance peroxide bleaching of kraft pulp by more than one mechanism. Its target substrates during prebleaching, which is more associated with bleach boosting, may differ from those during posttreatment, which is more associated with direct brightening. The former type of substrate could be the highly modified xylan that has reprecipitated back on fiber surfaces at the end of the kraft cook (Kantelinen et al., 1993), whereas the latter could be more or less native xylan or it could be xylan modified by bleaching liquors (Buchert et al., 1995). Also, the importance of either set of target substrates may depend on the bleaching chemicals, the former may have a greater role in chlorination that is directed at increasing the solubility of residual lignin in alkali, whereas the latter may be more important to oxidative bleaching with peroxide (Gierer, 1986). The occurrence of two types of substrates was suggested by the higher molecular mass of the water and alkaline-soluble lignin released by xylanase posttreatment as compared to xylanase prebleaching (de Jong et al., 1997a).

A result of the direct brightening achieved by a second xylanase treatment of peroxide bleached kraft pulps is a higher final pulp brightness. This was even observed in 
Aspen kraft pulp where brightness values of about $85 \%$ ISO were reached. An earlier report (Viikari et al., 1990) and two recent reports (Christov and Prior, 1996; Garg et al., 1996) have also suggested that a higher pulp brightness could be achieved in oxygen-based bleaching sequences if more than one xylanase stage are used. Further examination of this phenomenon, particularly concerning its occurrence in chlorine-based bleaching, could help elucidate the mechanism by which xylanase enhances pulp bleaching. From the perspective of mill applications, the economic and technical feasibility of using multiple xylanase stages in a bleaching sequence needs to be considered. The use of xylanase posttreatment instead of xylanase prebleaching could be favored by the configuration of certain mills. Our results indicate that a second xylanase treatment could be beneficial and that the importance attributed to bleach boosting needs to be reconsidered, particularly for its role in enhancing peroxide bleaching of kraft pulps.

We thank Howe Sound Pulp and Paper (Port Mellon, BC, Canada) for providing oxygen-delignified kraft pulp, and the Pulp and Paper Research Institute of Canada (Vancouver, BC, Canada) for the preparation kraft pulp and the use of their handsheet making and testing laboratories. We also thank Shawn Mansfield (University of British Columbia, Canada) for his assistance in determining pulp composition and for his review of this manuscript, and Sunny Lui for his assistance in determining the kappa number of pulp. Our work was partly financed by the Science Council of British Columbia and the Natural Sciences and Engineering Research Council of Canada.

\section{References}

Bailey, M. J., Biely, P., Poutanen, K. 1992. Interlaboratory testing of methods for assay of xylanase activity. J. Biotechnol. 23: 257-270.

Buchert, J., Teleman, A., Harjunpää, V., Tenkanen, M., Viikari, L., Vuorinen, T. 1995. Effect of cooking and bleaching on the structure of xylan in conventional pine kraft pulp. Tappi J. 78(11): 125-130.

Buchert, J., Carlsson, G., Viikari, L., Ström, G. 1996. Surface characterization of unbleached kraft pulps by enzymatic peeling and ESCA. Holzforschung 50: 69-74.

Christov, L. P., Prior, B. A. 1996. Repeated treatments with Aureobasidium pullulans hemicellulases and alkali enhance biobleaching of sulfite pulps. Enzyme Microb. Technol. 18: 244-250.

de Jong, E., Wong, K. K. Y., Martin, L. A., Mansfield, S. D., Gama, F. M., Saddler, J. N. 1997a. Molecular mass distribution of materials solubilized by xylanase treatment of Douglas-fir kraft pulp. ACS Symp. Series (in press).

de Jong, E., Wong, K. K. Y., Saddler, J. N. 1997b. The mechanism of xylanase prebleaching of kraft pulp: An examination using model pulps prepared by depositing lignin and xylan on cellulose fibers. Holzforschung (in press).

Dubois, M., Gilles, K. A., Hamilton, J. K., Rebers, P. A., Smith, F. 1956. Colorimetric method for determination of sugars and related substances. Anal. Chem. 28: 350-356.
Garg, A. P., McCarthy, A. J., Roberts, J. C. 1996. Biobleaching effect of Streptomyces thermoviolaceus xylanase preparations on birchwood kraft pulp. Enzyme Microb. Technol. 18: 261-267.

Gierer, J. 1986. Chemistry of delignification. Part 2: Reactions of lignins during bleaching. Wood Sci. Technol. 20: 1-33.

Hartler, N., Norrström, H. 1969. Light-absorbing properties of pulp and pulp components. III. Kraft pulp. Tappi J. 52: 1712-1715.

Hortling, B., Korhonen, M., Buchert, J., Sundquist, J., Viikari, L. 1994. The leachability of lignin from kraft pulps after xylanase treatment. Holzforschung 48: 441-446.

Kantelinen, A., Hortling, B., Sundquist, J., Linko, M., Viikari, L. 1993. Proposed mechanism of the enzymatic bleaching of kraft pulp with xylanases. Holzforschung 47: 318-324.

Lundgren, K. R., Bergkvist, L., Högman, S., Jöves, H., Eriksson, G., Bartfai, T., van der Laan, J., Rosenberg, E., Shoham, Y. 1994. TCF mill trial on softwood pulp with Korsnäs thermostable and alkaline stable xylanase T6. FEMS Microbiol. Rev. 13: 365-368.

Nelson, S. L., Wong, K. K. Y., Saddler, J. N., Beatson, R. P. 1995. The use of xylanase for peroxide bleaching of kraft pulps derived from different softwood species. Pulp Pap. Can. 96(7): 42-45.

Paice, M. G., Bernier, R. Jr., Jurasek, L. 1988. Viscosity-enhancing bleaching of hardwood kraft pulp with xylanase from a cloned gene. Biotechnol. Bioeng. 32: 235-239.

Pham, P. L., Alric, I., Delmas, M. 1995. Incorporation of xylanase in total chlorine free bleach sequences using ozone and hydrogen peroxide. Appita 48: 213-217.

Ragauskas, A. J., Poll, K. M., Cesternino, A. J. 1994. Effects of xylanase pretreatment procedures on nonchlorine bleaching. Enzyme Microb. Technol. 16: 492-495.

Schwartz, H., McCarthy, J. L., Hibbert, H. 1940. The "coloring matter" of kraft and its influence in bleaching. Paper Trade J. 111(18): 30-34.

Senior, D. J., Hamilton, J., Bernier, R. L., du Manoir, J. R. 1992. Reduction in chlorine use during bleaching of kraft pulp following xylanase treatment. Tappi J. 75(11): 125-130.

Suurnäkki, A., Kantelinen, A., Buchert, J., Viikari, L. 1994. Enzyme-aided bleaching of industrial softwood kraft pulps. Tappi J. 77(11): 111-116.

Suurnäkki, A., Heijnesson, A., Buchert, J., Westermark, U., Viikari, L. 1996. Effect of pulp surfaces on enzyme-aided bleaching of kraft pulps. J. Pulp Paper Sci. 22: J91-J96.

van Lierop, B., Liebergott, N., Faubert, M. G. 1994. Using oxygen and peroxide to bleach kraft pulps. J. Pulp Paper Sci. 20: J193-J198.

Viikari, L., Kantelinen, A., Poutanen, K., Ranua, M. 1990. Characterization of pulps treated with hemicellulolytic enzymes prior to bleaching. pp. 145-151. In: T.K. Kirk and H.-m. Chang (eds): Biotechnology in pulp and paper manufacture. Butterworth-Heinemann, Boston.

Viikari, L., Kantelinen, A., Sundquist, J., Linko, M. 1994. Xylanases in bleaching: from an idea to the industry. FEMS Microbiol. Rev. 13: 335-350.

Wong, K. K. Y., Saddler, J. N. 1992. Trichoderma xylanases, their properties and application. Crit. Rev. Biotechnol. 12: 413-435.

Wong, K. K. Y., Nelson, S. L., Saddler, J. N. 1996. Xylanase treatment for the peroxide bleaching of oxygen delignified kraft pulps derived from three softwood species. J. Biotechnol. 48: 137-145.

Yang, Y. L., Eriksson, K.-E. L. 1992. Use of hemicellulolytic enzymes as one stage in bleaching of kraft pulps. Holzforschung 46: 481-488.

Yokota, S., Wong, K. K. Y., Saddler, J. N., Reid, I. D. 1995. Molecular weight distribution of xylan/lignin mixtures from kraft pulps. Pulp Paper Can. 96(4): 39-41. 